\title{
PPM Pelatihan Pembuatan dan Pengelolaan Web SMA Dharma Wanita 4 Taman, Sidoarjo
}

\author{
Sumartono \\ Universitas Dr Soetomo
}

\author{
Boedi Martono \\ Universitas Dr Soetomo
}

Syaiful Hidayat

Universitas Dr Soetomo

\begin{abstract}
SMA Dharma Wanita 4 Taman Sidoarjo as the working partner of the Unitomo lecturer team, is a private school located on Jalan Kalijaten $1 B$ Taman Sidoarjo. As an educational institution, it requires adequate information facilities under the demands of the times. The official website for an educational institution is an unavoidable need. Therefore, the Dharma Wanita 4 Sidoarjo High School requires training for teachers and or employees to be able to manage the institution's website. The methods in the community service program now begin with brainstorming, field observations, conducting training on how to realize and manage the web, and ending with an evaluation in the form of monitoring the work of Unitomo lecturer team partners.
\end{abstract}

Keywords: SMA Dharma Wanita 4 Sidoarjo; Training; Web creation

\section{Abstrak}

SMA Dharma Wanita 4 Taman Sidoarjo sebagai mitra kerja tim dosen Unitomo, merupakan sekolah swasta yang berada di Jalan Kalijaten 1B Taman Sidoarjo. Sebagai institusi pendidikan sangat memerlukan sarana informasi yang memadai sesuai dengan tuntutan zaman. Web resmi untuk suatu institusi pendidikan adalah kebutuhan yang tidak dapat dihindari. Oleh sebab itu pihak sekolah SMA Dharma Wanita 4 Sidoarjo membutuhkan pelatihan untuk guru-guru dan atau karyawan untuk dapat mengelola web institusi tersebut. Adapun metode dalam program pengabdian pada masyarakat saat ini diawali dengan bertukar pikiran, observasi di lapangan, mengadakan pelatihan tentang bagaimana mewujudkan dan mengelola web, dan diakhiri dengan evaluasi berupa monitoring hasil kerja dari mitra tim dosen Unitomo.

Kata kunci: SMA Dharma Wanita 4 Sidoarjo; Pelatihan; Pembuatan web

\section{Pendahuluan}

SMA Dharma Wanita 4 Taman, Sidoarjo terletak di jalan Kalijaten 1B, Kelurahan Kalijaten, Kecamatan Taman, Kabupaten Sidoarjo, Provinsi Jawa Timur. Sekolah ini berdiri sejak tahun 1983, dengan SK pendirian No. 1441/104.12/T4.83 tanggal 19 September 1983. Sekolah ini berstatus swasta yang dikelola oleh yayasan Dharma Wanita Persatuan Sidoarjo.

SMA Dharma Wanita 4 Taman, Sidoarjo, merupakan institusi lembaga pendidikan yang berstatus swasta dengan SK pendirian Sekolah ini diselenggarakan oleh Sekolah ini berdiri di lahan seluas kurang lebih $3.600 \mathrm{~m}^{2}$, yang terletak di jalan Kalijaten 1B Taman, Sidoarjo, terletak di kawasan padat penduduk.

SMA Dharma Wanita 4 memiliki dua jurusan yaitu jurusan IPA dan IPS, dengan dua rombongan belajar per tingkatan kelas. Jumlah siswa keseluruhan rata-rata 210 per tahunnya. Jika dilihat dari segi tingkat perelkonomian siswanya, yang belajar di SMA Dharma Wanita 4 ini rata-rata dari siswa yang memiliki tingkat ekonomi menengah ke bawah. Adapun besaran SPP yang dikenakn ke siswa tidaklah mahal yakni Rp200.000,00. Besaran ini cukup terjangkau bagi siswa dengan tingkat ekonomi menengah ke bawah. 
SMA Dharma Wanita 4 ini, memiliki tingkat persaingan yang tinggi dengan sekolahsekolah di sekitarnya. Dalam radius $10 \mathrm{~km}$ dari titik keberadaan SMA Dharma Wanita 4, setidaknya ada empat sekolah swasta (Yakni SMA YPM, SMA Muhammadiyah, SMA Ulul Albab, dan SMA yang dikelola oleh Yayasan Al Banath) yang saling bersaing dalam memperebutkan kepercayaan masyarakat sekitar untuk menyekolahkan anak mereka di sekolah yang bermutu sekaligus terjangkau.

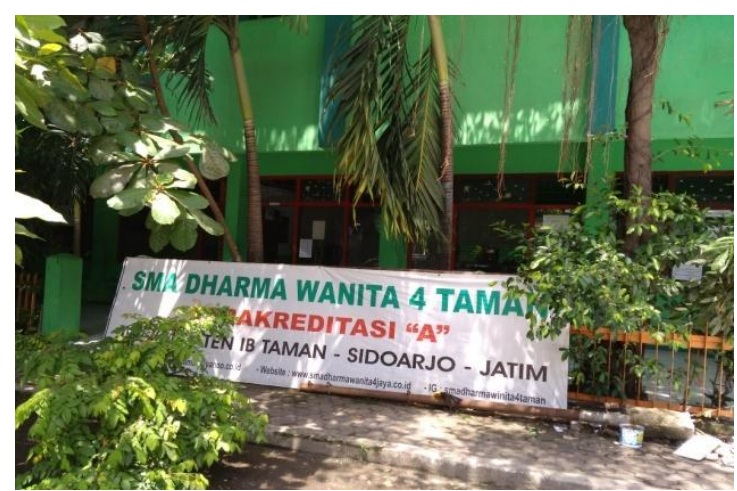

Gambar 1. Papan nama sekolah

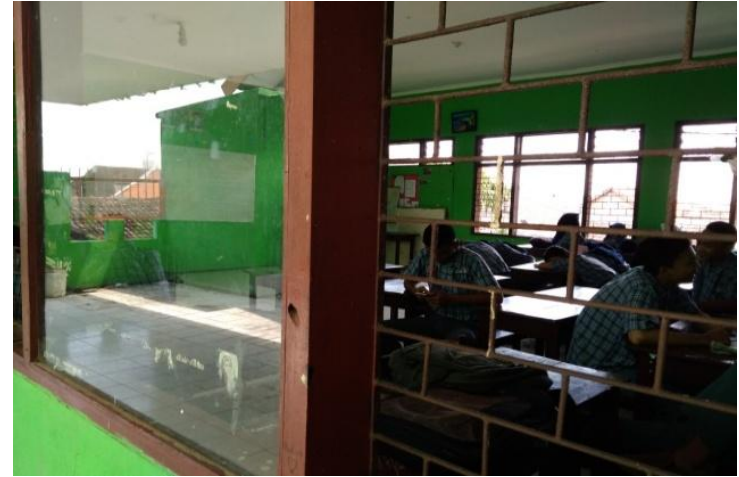

Gambar 2. Sudut ruang kelas

Berikut kondisi yang terdapat di SMA Dharma Wanita 4 Taman Sidoarjo.

\begin{tabular}{|c|c|c|c|}
\hline No. & Potensi Mitra & Permasalahan & Keterangan \\
\hline 1 & SDM & $\begin{array}{l}\text { Jumlah Guru : } 37 \text { orang, terdiri atas } \\
\text { - S3 : - } \\
\text { - S2 : } 2 \text { orang } \\
\text { - S1 : } 19 \text { orang } \\
\text { - SMA : } 2 \text { orang } \\
\text { Tenaga TU } 3 \text { orang } \\
\text { Akreditasi Sekolah > 30\% harus S2 } \\
\text { Kepala Sekolah Harus berkualifikasi S2. }\end{array}$ & Perlu ditingkatkan \\
\hline 2 & Statistik & $\begin{array}{l}\text { Jumlah siswa : } 132 \\
\text { Jumlah Rombongan Belajar : } \\
\text { Kelas III }: 2 \\
\text { Kelas II }: 2 \\
\text { Kelas I }: 2\end{array}$ & $\begin{array}{l}\text { Bisa ditingkatkan } \\
\text { jumlah penerimaan } \\
\text { siswanya }\end{array}$ \\
\hline 3 & Ipteks & 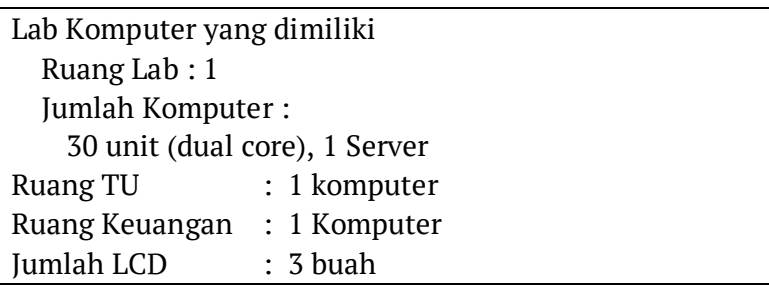 & $\begin{array}{l}\text { Masih perlu } \\
\text { ditingkatkan }\end{array}$ \\
\hline 4 & PBM & $\begin{array}{l}\text { Di ruang PBM disediakan LCD portable, Access Point dan } \\
\text { Sound sentral. } \\
\text { Memiliki } 2 \text { jurusan : IPA dan IPS }\end{array}$ & Bisa dikembangkan \\
\hline 5 & Fasilitas & $\begin{array}{ll}\text { Gedung sekolah } & : 2 \text { lantai } \\
\text { Lokal } & : 3.600 \mathrm{~m}^{2} \\
\text { Bangunan } & : 2.365 \mathrm{~m}^{2} \\
\text { Ruang Guru } & : 1 \\
\text { Ruang UKS } & : 1 \\
\text { Ruang Osis } & : 1 \\
\text { Ruang UKS } & : 1 \\
\text { Ruang Koperasi } & : 1 \\
\text { Ruang BK } & : 1 \\
\text { Ruang perpus } & : 1 \\
\text { Ruang TU } & : 1\end{array}$ & $\begin{array}{l}\text { Bisa ditingkatkan } \\
\text { peralatan, sarana, } \\
\text { dan prasarananya }\end{array}$ \\
\hline
\end{tabular}




\begin{tabular}{|c|c|c|c|}
\hline No. & Potensi Mitra & Permasalahan & Keterangan \\
\hline 6 & $\begin{array}{l}\text { Manajemen } \\
\text { Pemasaran }\end{array}$ & $\begin{array}{l}\text { - Lisan } \\
\text { - Spanduk } \\
\text { - Brosur }\end{array}$ & $\begin{array}{l}\text { Bisa ditingkatkan } \\
\text { dengan manajemen } \\
\text { pemasaran berbasis } \\
\text { IT, peningkatan } \\
\text { brand image sekolah }\end{array}$ \\
\hline 7 & $\begin{array}{l}\text { Manajemen } \\
\text { Keuangan }\end{array}$ & $\begin{array}{l}\text { - Operasional sekolah sepenuhnya dari Uang Gedung dan } \\
\text { uang SPP siswa yang dibayar setiap bulan, yang digunakan } \\
\text { untuk membayar gaji guru dan karyawan. } \\
\text { - Beberapa pembangunan ruang dibantu oleh beberapa } \\
\text { parpol. }\end{array}$ & $\begin{array}{l}\text { Perlu usaha untuk } \\
\text { meningkatkan } \\
\text { income sekolah }\end{array}$ \\
\hline
\end{tabular}

Dari beberapa item yang telah disebutkan sebelumnya, ada beberapa item yang mendapat prioritas utama sebagai permasalahan SMA Dharma Wanita 4 yang membutuhkan untuk segera diwujudkan, yakni web resmi sekolah.

Mengingat saat ini adalah era digital, segalanya dikelola dengan proses digitalisasi, maka keberadaan web merupakan hal yang tidak dapat ditinggalkan oleh sekolah sebagai institusi pendidikan. Dengan adanya web resmi institusi, segala informasi dari pihak sekolah akan terakses dengan mudah untuk khalayak umum, khususnya sangat berguna bagi siswa-siswa mereka. Hal ini juga dapat dipakai sebagai sarana promosi yang efektif di lingkungan masyarakat sekitar (Surahman 2019).

Mengacu pada butir analisis situasi, dapat diidentifikasi permasalahan pada mitra meliputi beberapa hal berikut ini:

a. SMA Dharma Wanita, belum memiliki web resmi sebagai situs resmi yang dapat menjadi rujukan valid dari pihak sekolah.

b. Belum adanya guru atau karyawan yang mampu mengelola web institusi.

\section{Metode Pelaksanaan}

Berdasarkan uraian sebelumnya, serta hasil diskusi dengan mitra, maka prioritas permasalah yang harus diselesaikan bersama mitra adalah memperkenalkan seluk beluk web dan kegunaannya, pelatihan dan pendampingan bagi guru atau karyawan dalam mengelola web, pendampingan untuk mewujudkan adanya web resmi SMA Dharma Wanita 4 Taman Sidoarjo.

Pelaksanaan program pengabdian masyarakat yang dilaksanakan ini memiliki tahapantahapan sebagaimana berikut.

a. Perencanaan Awal; Dari sekian mitra, akhirnya tim dosen memutuskan menjalin kerjasama dengan SMA Dharma Wanita 4 Taman-Sidoarjo, dengan alasan adanya alumni dari FKIP Universitas Dr. Soetomo yang menjadi pengajar di sana. Alasan berikutnya adalah sumber daya manusia SMA Dharma Wanita 4 Taman, Sidoarjo memerlukan pelatihan pembuatan dan pengelolaan web. Alasan ketiga, Salah satu tim dosen sudah pernah menjalin kerjasama dengan SMA Dharma Wanita dalam hal pengabdian di tahun 2017-2018, sehingga program pengabdian ini adalah bentuk lanjutan dari pelaksanaan pengabdian tahun sebelumnya, sebagai wujud pelaksanaan Tri Dharma Perguruan TInggi.

b. Identifikasi awal dengan mitra; pada tahap ini tim dosen dibantu mahasiswa dan alumni yang mengajar di sana, menjajagi dengan mitra tentang program pengabdian masyarakat. Identifikasi ini meliputi beberapa keadaan yang perlu ditangani bersama. Dari beberapa permasalahan, dipilih prioritas yang cukup mendesak yang dihadapi adalah pengadaan web resmi dan cara mengadakan serta mengelolanya. Guru-guru atau karyawan yang ditunjuk pihak pimpinan SMA Dharma Wanita 4 Taman Sidoarjo, memerlukan pelatihan pengadaan dan pengelolaan web. Oleh sebab itu tim dosen menawarkan penyuluhan dan pelatihan ke guru-guru tentang cara pembuatan dan pengelolaan web resmi institusi pendidikan yang memang telah menjadi keahlian dari tim dosen FKIP dan dosen Fakultas Teknik Unitomo. 
Setelah kedua belah pihak setuju, dibuatlah surat kerjasama antara kedua belah pihak sebagai tanda bahwa ada kerjasama yang syah antara keduanya. Kemudian disetujui tanggal pelaksanaan pelatihan.

c. Tahap Pelaksanaan; pada tahap ini dilaksanakan pelatihan dengan metode terbimbing terhadap guru-guru SMA Dharma Wanita 4 Taman Sidoarjo. Dalam pelatihan ini seluruh akomodasi dan perlengkapan serta persiapan pelatihan ditanggung bersama antara pihak tim dosen dibantu oleh pihak SMA Dharma Wanita 4 Taman Sidoarjo dan dua mahasiswa FKIP. Penggandaan materi digandakan oleh tim dosen. Untuk materinya dari pihak tim abdi masyarakat, telah kompeten di bidang pembuatan web. Hanya saja perlu juga sebelumnya para guru dan staf yang ditunjuk diberi arahan sedikit referensi untuk membuat web. Diantara referensi yang disarankan oleh tim pengabdi masyarakat adalah karya (Nilasari 2014), (Setiawan 2018), (Surahman 2019), (Raharjo, Heryanto, and K 2015), dan (Prawiyanto 2018). Referensi ini hanya untuk membua selayang pandang bagi peserta pelatihan. Selebihnya pelatihan langsung dari tim pengabdi masyarakat Unitomo. Pada tahap ini acara dibuka oleh kepala sekolah SMA Dharma Wanita 4 Taman Sidoarjo., kemudian acara dilanjutkan dengan pelatihan oleh tim dan pendampingan dosen. Pada tahap ini terbagi dalam dua kali pelatihan dan empat kali pendampingan (baik secara tatap muka atau nontatap muka) dengan durasi waktu per tatap muka 6 jam. Pendampingan, komunikasi, dan diskusi dilakukan melalui media sosial.

d. Tahap Evaluasi Pelaksanaan; pada tahap ini dilaksanakan evaluasi yang dilakukan oleh tim dosen dibantu dengan mitra.

e. Tahap Pelaporan Hasil Kegiatan; pada tahap ini disusun laporan program pengabdian masyarakat oleh tim dosen. Laporan ini akan diserahkan ke LPM dan pihak mitra sebagai bentuk pertanggungjawaban secara tertulis dari pihak tim dosen.

Adapun prosedur kerja dapat digambarkan sebagai berikut

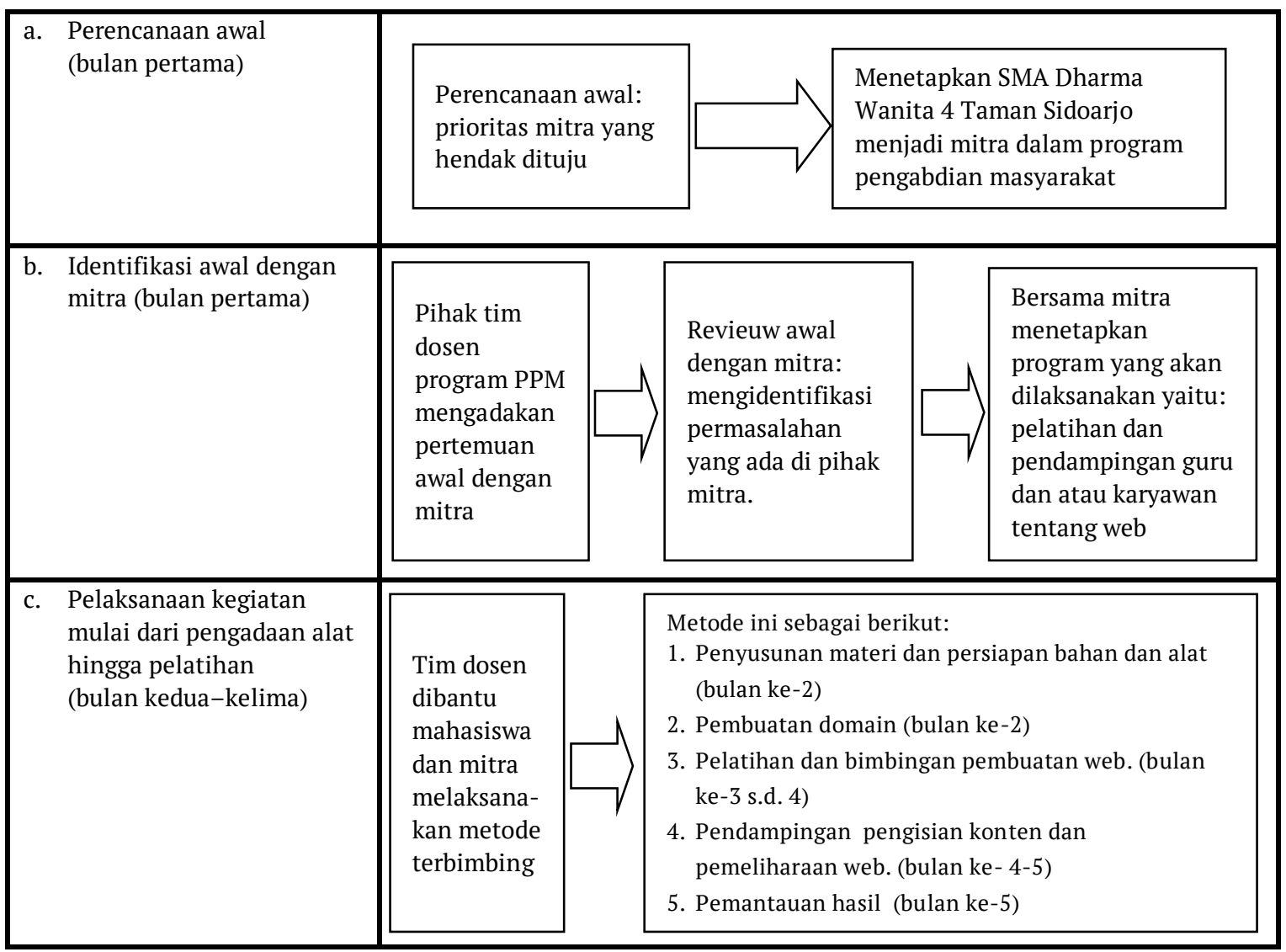




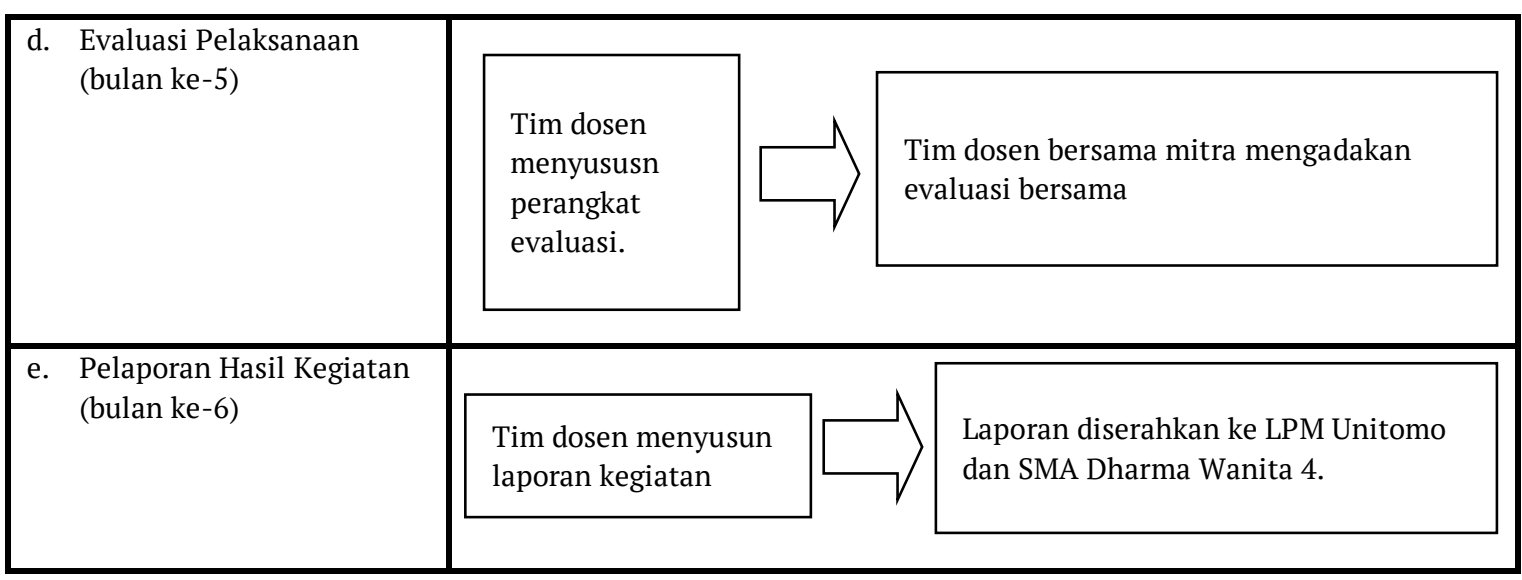

\section{Hasil dan Pembahasan}

Program Pengabdian Masyarakat yang bermitra dengan SMA Dharma Wanita 4 Taman Sidoarjo ini memiliki target luaran adanya web di instansi tersebut sebagai wadah informasi tentang keberadaan instansi tersebut. Dengan adanya web diharapkan mampu berdaya guna bagi instansi dan masyarakat pengguna yang menginginkan informasi tentang keberadaan SMA Dharma Wanita 4 Taman Sidoarjo. Adapun ketercapaian hasil program pengabdian masyarakat tampak dalam Tabel 1.

Tabel 1. Aktivitas dan Kebutuhan Materi Web

\begin{tabular}{clll}
\hline No. & Aspek & Sebelum & Sesudah \\
\hline 1 & $\begin{array}{l}\text { Pemahaman kegunaan } \\
\text { keberdaan web bagi institusi }\end{array}$ & $\begin{array}{l}\text { Belum merasa penting karena } \\
\text { belum ada bayangan }\end{array}$ & $\begin{array}{l}\text { Paham akan pentingnya } \\
\text { keberadaan web bagi institusi } \\
\text { sekolah swasta. }\end{array}$ \\
\hline 2 & $\begin{array}{l}\text { Cara awal pemerolehan domain } \\
\text { web }\end{array}$ & Belum ada bayangan & $\begin{array}{l}\text { Sudah mampu membuat domain } \\
\text { web }\end{array}$ \\
\hline 3 & $\begin{array}{l}\text { Cara mengisi template tag line } \\
\text { dan logo di web }\end{array}$ & Belum mampu & $\begin{array}{l}\text { Mampu mengisi template tag } \\
\text { line dan logo yang tersedia } \\
\text { dengan hasil yang sederhana }\end{array}$ \\
\hline 4 & Cara membuat menu bar di web & Belum mampu & $\begin{array}{l}\text { Sudah mampu membuat menu } \\
\text { di web }\end{array}$ \\
\hline 5 & $\begin{array}{l}\text { Mengisi secara sederhana } \\
\text { template menu di web }\end{array}$ & Belum mampu & $\begin{array}{l}\text { Sudah mampu mengisi } \\
\text { template-template secara } \\
\text { sederhana }\end{array}$ \\
\hline
\end{tabular}

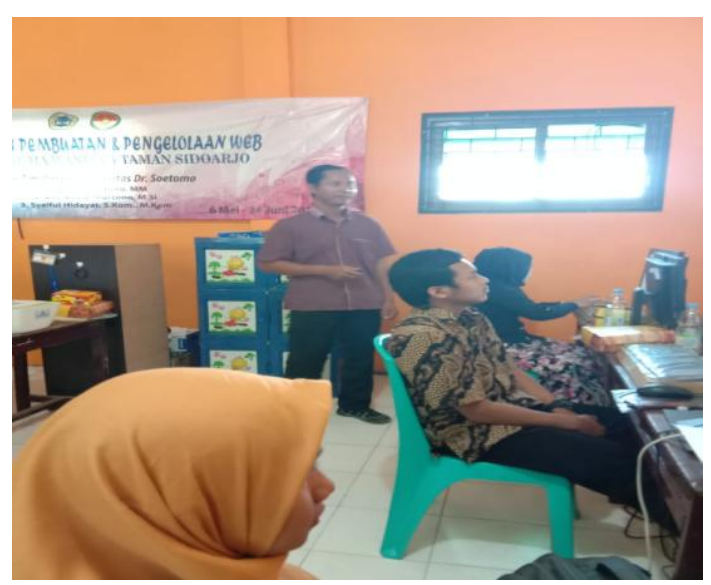

Gambar 3. Salah satu tim dosen memberi pelatihan

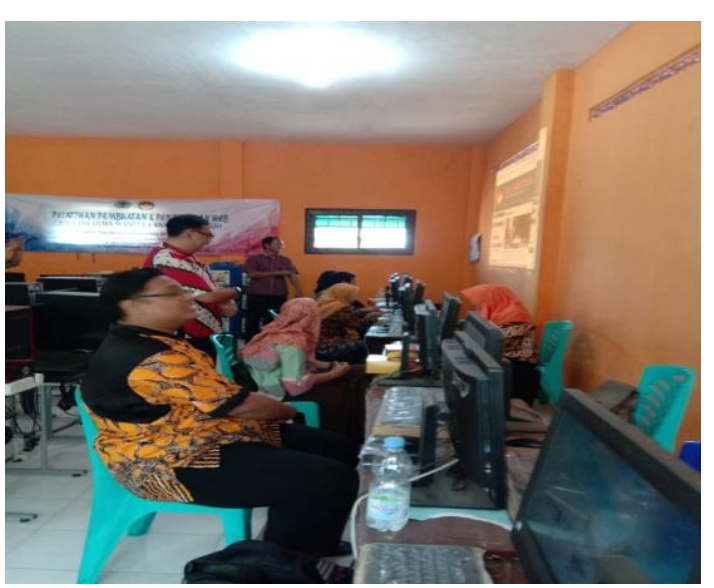

Gambar 4. Suasana pelaksanaan pelatihan 
Adapun luaran yang sudah berhasil dicapai dalam rangkaian kegiatan keseluruhan terlihat pada Tabel 2.

Tabel 2. Luaran yang Berhasil Dicapai dalam Kegiatan

\begin{tabular}{cll}
\hline No. & Luaran & Capaian \\
\hline 1 & Jasa Pelatihan berupa penyuluhan dan pelatihan & $100 \%$ (selama lima bulan) \\
2 & Produk: web SMA Dharma Wanita 4 Taman Sidoarjo dengan alamat web & $100 \%$ \\
& http://smadharmawanita4taman.sch.id.smartjaya.co.id & $100 \%$
\end{tabular}

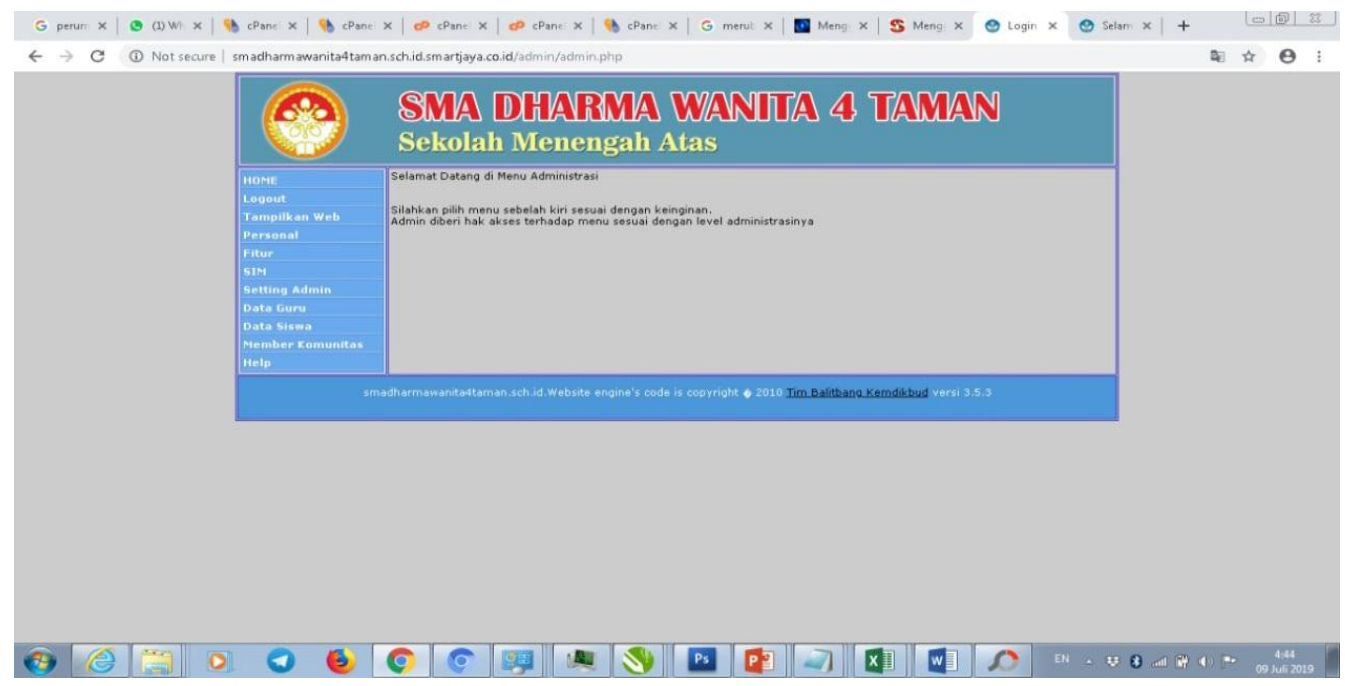

Gambar 5. Hasil screenshot login para admin web Dharma Wanita 4 Sidoarjo

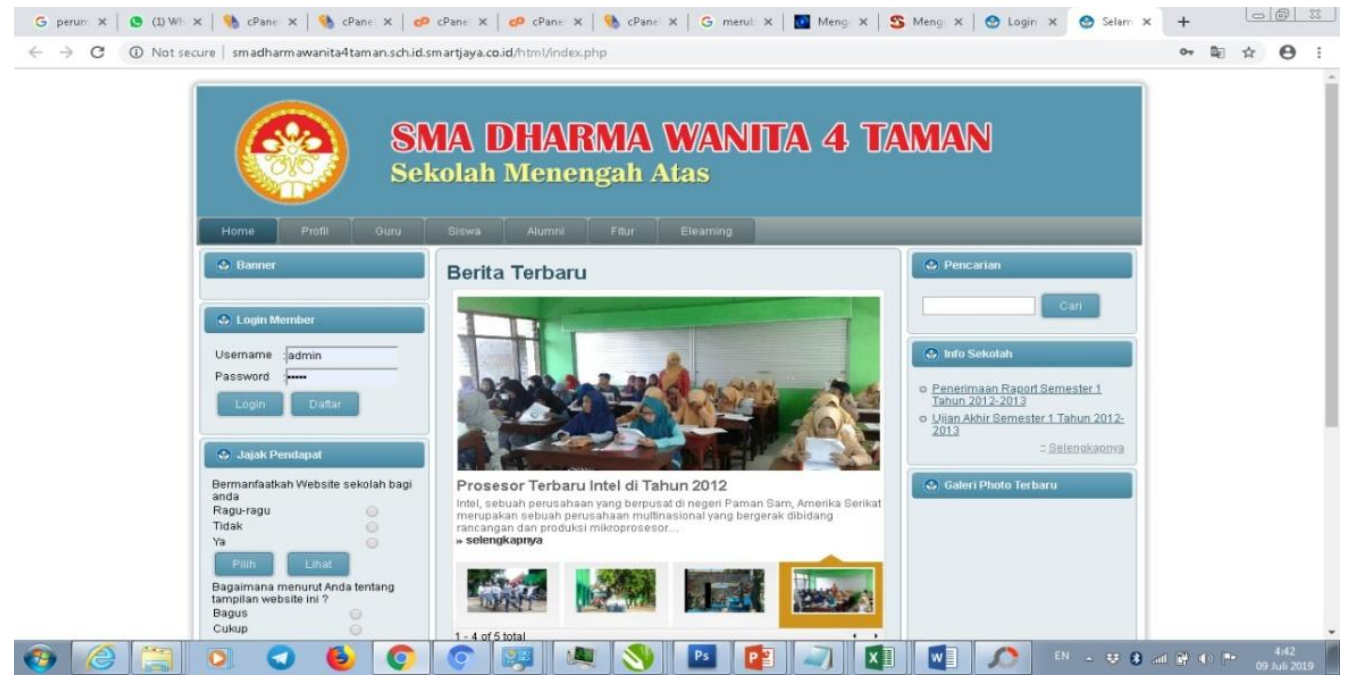

Gambar 6. Hasil screenshot tampilan web SMA Dharma Wanita 4 Sidoarjo

Dalam hal pelaksanaan yang berupa jasa pelatihan pembuatan dan pengelolaan web untuk karyawan dan atau guru pengelola web SMA Dharma Wanita 4 Sidoarjo, produk jadi berupa web instansi, berlangsung dengan baik dan tuntas $100 \%$. Pelatihan tersebut diikuti delapan guru dan karyawan yang telah ditunjuk oleh kepala sekolah. Pelatihan dilakukan secara tatap muka dan konsultasi melalui media sosial. Luaran berupa produk yakni domain web resmi SMA Dharma Wanita 4, Taman, Sidoarjo dapat dibuka pada laman http:// smadharmawanita4taman.sch.id.smartjaya.co.id. 


\section{Kesimpulan}

Adanya kerjasama antara mitra kerja (yang dalam hal ini SMA Dharma Wanita 4, Taman, Sidoarjo) dengan tim Pengabdian Masyarakat dosen Universitas Dr. Soetomo Surabaya, membuahkan hasil yang sangat baik. Guru-guru dan staf yang ditugaskan oleh pihak sekolah SMA Dharma Wanita 4 Taman Sidoarjo, seluruhnya paham cara pengaturan konten dalam web tersebut. Dari rencana program pengabdian yang telah disusun, dapat disimpulkan terlaksana 100\% pada akhir kegitan. Kendala yang ditemui bukan persoalan pengelolaan web, tapi lebih pada penyusunan narasi dalam menyampaikan konten-konten web. Diharapkan dengan adanya web yang sudah diajarkan cara pembuatan dan pengelolaan oleh tim dosen pengabdi masyarakat membawa manfaat yang maksimal bagi pihak mitra kerja.

\section{Ucapan Terima Kasih}

Tim pengabdian masyarakat mengucapkan banyak terima kasih kepada pihak rektorat Universitas Dr. Soetomo Surabaya yang telah mendukung penuh, baik secara materiel dan morel untuk melaksanakan program pengabdian masyarakat. Berikutnya, tim pengabdian masyarakat juga mengucapkan terima kasih kepada pihak Kepala Sekolah dan jajaran SMA Dharma Wanita 4, Taman, Sidoarjo yang dengan antusias menyambut baik hubungan kerja sama dengan pihak Universitas Dr. Soetomo Surabaya. Tidak lupa, ucapan terima kasih tertuju pada mahasiswa kami yakni Arif Wibowo dan alumni kami yang sudah bekerja di SMA Dharma Wanita 4 Sidoarjo, yakni ananda Ani. Dengan adanya mahasiswa dan alumni ini, pelaksanaan kegiatan pengabdian menjadi lebih mudah serta berjalan dengan baik dan lancar.

\section{Daftar Pustaka}

Nilasari, Senja. 2014. Jago Membuat Website Gratis \& Cepat Secara Otodidak - Edisi Terbaru. Dunia Komputer. https://www.bukukita.com/Komputer-dan-Internet/Web-Design /125710-Jago-Membuat-Website-Gratis-\&-Cepat-Secara-Otodidak-Edisi-Terbaru.html.

Prawiyanto, dkk. 2018. "Pemrograman Web Dan Perangkat Bergerak - Program Keahlian Teknik Kompu.” Https://Andipublisher.Com/ (blog). 2018. https://andipublisher.com/produk0918006774-pemrograman-web-dan-perangkat-bergerak--.html.

Raharjo, Budi, Imam Heryanto, and E. Rosdiana K. 2015. Modul Pemrograman Web HTML, PHP \& MySQL Revisi Kedua. Modula. https://openlibrary.telkomuniversity.ac.id/pustaka/99894 /modul-pemrograman-web-html-php-mysql-revisi-kedua.html.

Setiawan, Didik. 2018. Buku Sakti Pemrograman Web: HTML, CSS, PHP, MySQL \& Javascript. Start Up. https://openlibrary.telkomuniversity.ac.id/pustaka/141549/buku-sakti-pemrograman -web-html-css-php-mysql-javascript.html.

Surahman, Su. 2019. "LAPORAN AKHIR TAHUN ANGGARAN 2018/2019 PROGRAM PENGABDIAN MASYARAKAT,” 31. 


\section{Afiliasi:}

Sumartono ${ }^{(\star)}$, Boedi Martono

FKIP, Universitas Dr. Soetomo, Surabaya

Jl. Semolowaru 84, Surabaya

E-mail : sumartono@unitomo.ac.id( $\left.{ }^{(}\right)$, budi.martono@unitomo.ac.id

\section{Syaiful Hidayat}

FT, Universitas Dr. Soetomo, Surabaya

Jl. Semolowaru 84, Surabaya

E-mail : syaiful.hidayat@unitomo.ac.id 